\title{
SMALL SAMBAQUIS AND BIG CHRONOLOGIES: SHELLMOUND BUILDING AND HUNTER-GATHERERS IN NEOTROPICAL HIGHLANDS
}

\author{
Levy Figuti ${ }^{1,2}$ • Cláudia R Plens ${ }^{3} \cdot$ Paulo DeBlasis $^{1}$
}

ABSTRACT. Sambaquis, famous Brazilian coastal shellmounds, represent a successful and long archaeological cultural tradition, with hundreds of sites spread over $2000 \mathrm{~km}$ of the Brazilian south-southeast coastline. These sites have many burials within a sequence of layers comprising a mix of faunal remains, charcoal, ashes, and sand, thus resulting in very complex stratigraphic structures. Several radiocarbon samples exhibit ages between 8000 and $1000 \mathrm{cal}$ yr BP. In the Brazilian southeastern coastal hinterland, at the Ribeira de Iguape basin, 36 small mounds similar to the sambaquis were found, composed mostly of landsnail shells, bone remains of terrestrial fauna, lithic and osteodontological artifacts, and quite a few burials. Through the last decade an archaeological research project has accomplished extensive surveys and systematic ${ }^{14} \mathrm{C}$ sampling, together with excavations in selected sites. A sequence of ages has been obtained from different samples (16 on shell, 10 on human bone, and 6 on charcoal) representing 19 sites. These dates range from 10,000 to $1000 \mathrm{cal}$ yr BP, highlighting around $9000 \mathrm{yr}$ of cultural continuity, contemporary to both the Paleoindian record over the hinterland plateau, and older than their coastal counterparts, the sambaquis. By presenting the ${ }^{14} \mathrm{C}$ distribution and an overview of the archaeological features of these sites, we discuss briefly the dispersion and settlement processes of early peopling in this area of Brazil.

\section{INTRODUCTION}

Occupation of the Brazilian southeast region during the Archaic shows a contrast between the extensive shoreline and the vast inland plateau, with no clear evidence of contacts between these huge areas (Schmitz 1987; Prous 1992). Throughout the southern highland plateau, hunter-gatherer traditions, the Umbu and Humaitá, displaying rather distinctive lithic technological features, have evolved until the emergence of Formative (ceramic) settlements, and even after that, in some refuge areas (Schmidt-Dias 2012).

On the other side of the mountainous escarpments, dense occupations have been detected along the coastal plains, where hundreds of sambaquis (or shellmounds) are found, most of them concentrated in very productive bay and estuarine environments (Gaspar et al. 2008). The distinctiveness of their technology and adaptive characteristics compared to their planaltic counterparts have long been recognized (e.g. Willey 1971; see also DeBlasis et al. 1998) and, as far as the main cultural trends of these areas are considered, no models of transcultural relations, such as transhumance, have been satisfactorily advanced so far (Prous 1992).

In some areas, however, deep valleys where continental and coastal environments meet in a soft-gradient topography and a rather mingling way in ecological terms, numerous lithic sites and a few caves and shelters are found. Into the sheltered sites, some evidence of contact between these otherwise parted cultural domains have been detected, usually in the form of Umbu lithic assemblages displaying some artifacts and shellfish from marine provenience (e.g. Miller 1969). Although these sites are rare and scattered towards the escarpments of the Atlantic Plateau, their occasional presence suggests that, in some areas, contacts between these cultures might have happened in more ways than we have been able to detect so far. The Ribeira de Iguape Valley, discussed in this paper, is one of these propitious zones for cultural conectivity.

\footnotetext{
${ }^{1}$ Museu de Arqueologia e Etnologia da Universidade de São Paulo - MAE, Avenida Professor Almeida Prado, 1466 - Cidade Universitária, Brazil.

${ }^{2}$ Corresponding author. Email: Ifiguti@usp.br.

${ }^{3}$ Departamento de História da Universidade Federal de São Paulo - UNIFESP - Estrada do Caminho Velho, Bairro dos Pimentas, São Paulo, Brazil.
}

(C) 2013 by the Arizona Board of Regents on behalf of the University of Arizona Proceedings of the 21st International Radiocarbon Conference edited by A J T Jull \& C Hatté RADIOCARBON, Vol 55, Nr 2-3, 2013, p 1215-1221 


\section{Figuti et al.}

Deep into this valley, and rather away from the coast, there are small mounds composed mostly of landsnail shells, the sambaquis fluviais (riverine sambaquis), so called because they usually stand by lowland hinterland riverside areas, on older and elevated (non-flooding) terraces or lower hillslopes. An archaeological and geophysical investigation program, carried out between 1999 and 2004, brought to light the structural, cultural, and bioarchaeological characteristics of these hinterland sambaquis (briefly examined in the next section), also revealing an enduring, previously unsuspected chronology.

\section{BACKGROUND}

The riverine sambaquis occupy a subtropical coastal backland region, mostly spread in 3 areas of the Ribeira Valley (Barreto 1988): the Jacupiranga basin to the south, the Juquiá basin to the north and, to the west, the Itaoca area (Figure 1). Between the coastal plains and the inland plateau, the Ribeira de Iguape basin comprises escarpments and intermontane valleys $200-1200 \mathrm{~m}$ asl, supporting a rich and highly diversified ecosystem mainly composed of lush tropical Atlantic rainforest (Mata Atlântica).

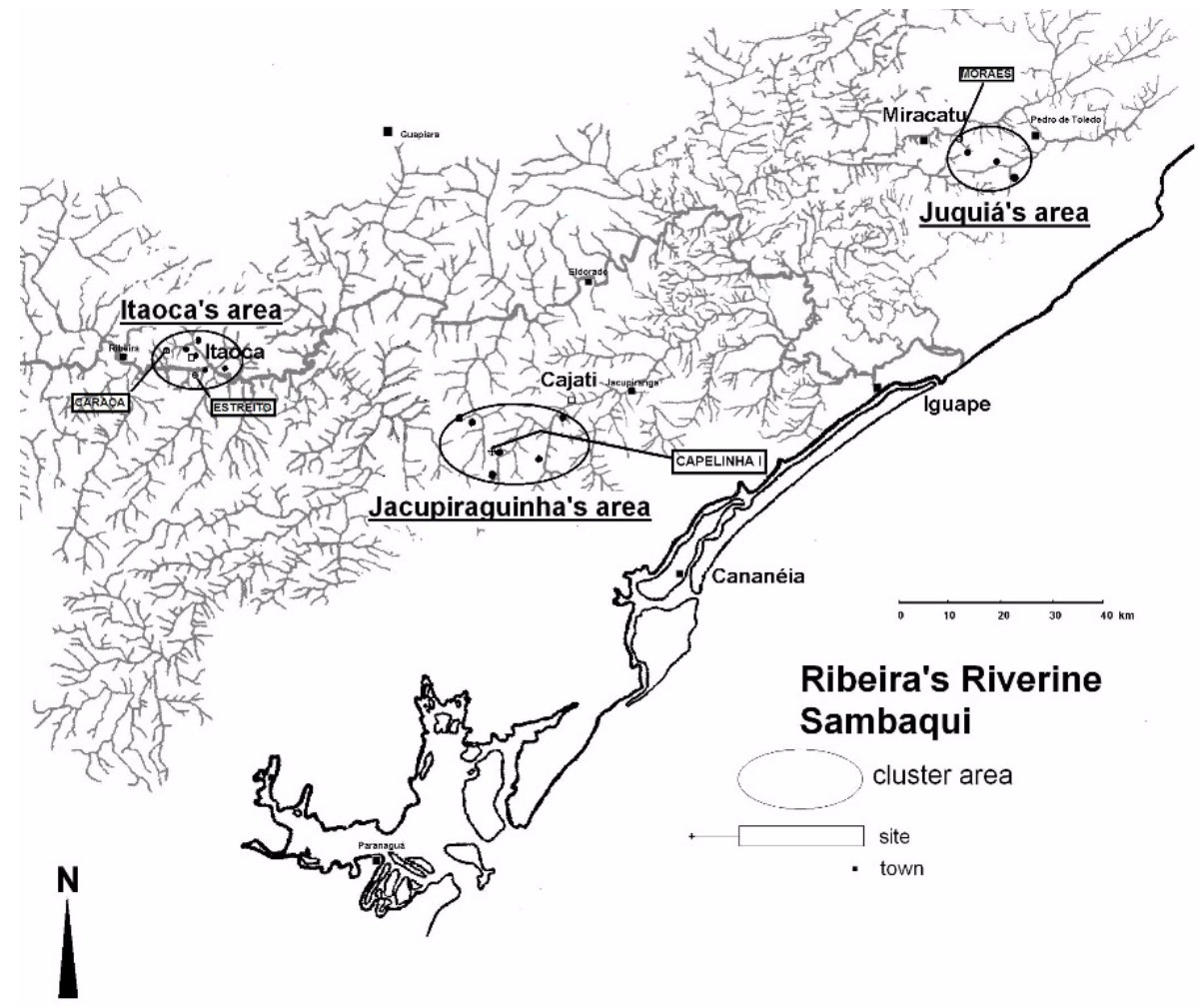

Figure 1 Map of the studied area

These mounded sites, round or elliptical in shape, average $1000 \mathrm{~m}^{2}$ in area and are no higher than $2 \mathrm{~m}$. Never stratigraphically homogeneous, they typically comprise a 2-layered structure with black organic-rich sediment packed with shells under a more grayish earthen material with less shell and organic remains. Despite an apparent internal homogeneity, these larger packages usually display tiny layering composed of the same sort of materials, configuring localized sequences not common 


\section{Small Sambaquis and Big Chronologies}

to the whole site. Archaeological features are mostly burials, with shell pockets and hearths associated with them. Burials display a variety of patterns, including different body positioning (often laterally flexed), secondary deposition and cremation (Plens 2007).

Other materials seem dispersed into the sediments. Lithic tools are mostly expedient, with occasional sophisticated polished artifacts; osteodontokeratic artifacts are mainly teeth beads and adornments, antlers, points, and hooks. Lots of faunal remains are to be found in the sediments, and the taxonomic composition can vary from assemblages of small mammal remains with significant amounts of amphibians, to mixed assemblages of mammals and fish (Plens 2007; Alves 2008; Borges 2009).

Larger excavations in a few of these sites (mostly Moraes and Capelinha, but also Caraça and Lajeado IV) have shown that their principal characteristics are moundbuilding related to funerary ritual, with extensive use of shell materials (mostly Megalobulimus sp., a large landsnail) in the mounding-up process. The archaeological record also suggests that the abundant faunal remains found all around (within and encircling the mound) are related to funerary feasting, since no clear evidence for habitation or everyday activity areas have been detected. Although the occasional consumption of terrestrial or riverine mollusks is not uncommon at planaltic settlements, the structuring of these mounds evoke, in a rather dramatic manner, the funerary-bound moundbuilding processes recently described for the coastal sambaquis (Gaspar et al. 2008; Fish et al. 2013). This relationship is also emphasized by the discreet presence of maritime species among the faunal remains and artifacts of these inland sites indicating contacts with the coast, even if infrequent.

A few of these riverine mounds exhibit assorted lithics of the Umbu style, notably at Capelinha, where an impressive amount of projectile points typical of that tradition, and related façonnage remains, are dispersed throughout the 2-m-thick stratigraphy of the mound. Umbu lithic technology has also been found at some other sites (e.g. Laranjal, Capelinha II, and Batatal) into or under the mounds. Penin (2005), analyzing the depositional context at Capelinha, has concluded that Umbu materials are provenient from a later deposition, mingled into the mound due to postdepositional processes, mainly bioturbation, a controversial interpretation (see e.g. Morais 2000). Thus, the "delicate" relationships between these usually separate coastal and planaltic cultures, as well as the antiquity of such contacts, and the supposedly coastal provenience of these riverine mounds, are among the many interpretive questions raised regarding these peculiar sites, all of them requiring a tight chronological control, the central focus of this paper.

\section{DATING}

Regarding sampling, field procedures prioritized recognizable archaeological features such as burials, shell layers, and occasional thin charcoal lenses. Shell and charcoal samples were collected from well-described stratigraphical contexts into excavated areas, and dried in at low temperature in a stove. Human bone and teeth samples were collected in the lab, after cleaning and curation procedures.

From the 36 riverine sambaquis known in the area, 19 sites were sampled and $28{ }^{14} \mathrm{C}$ ages obtained, in most cases from a few samples (usually top and bottom) collected in small stratigraphically controlled test excavations. In some sites, particularly Capelinha and Moraes, however, larger excavation areas have better exposed the stratigraphical layering, revealing a large number of burials associated with other features, where several samples were collected. The obtained ages have revealed a surprisingly long chronology for these riverine mounds, from 10,500 to 1000 cal yr BP (Table 1). 


\section{Figuti et al.}

Table 1 Radiocarbon dates for the riverine sambaquis from the Ribeira Valley.

\begin{tabular}{|c|c|c|c|c|c|}
\hline Site & $\begin{array}{l}\text { Depth } \\
(\mathrm{cm})\end{array}$ & $\begin{array}{l}\text { Conventional } \\
{ }^{14} \mathrm{C} \text { age }\end{array}$ & cal BP & Sample type & Lab nr \\
\hline Capelinha I & $10-20$ & $9250 \pm 50$ & $10,560-10,250$ & Shell & Beta 189331 \\
\hline Batatal I & $50-60$ & $9050 \pm 100$ & $10,415-9915$ & Shell & Beta 189329 \\
\hline Capelinha I & $0-30$ & $8860 \pm 60$ & $10,180-9710$ & Bones (burial 2) & Beta 153988 \\
\hline Capelinha I & $90-100$ & $8795+105 /-100$ & $9963-9539$ & Charcoal & A 11239 \\
\hline Capelinha I & $80-90$ & $8500 \pm 70$ & $9544-9293$ & Shell & A 11236 \\
\hline Laranjal & $40-50$ & $6980 \pm 90$ & $7965-7645$ & Shell & Beta 189337 \\
\hline Capelinha I & $10-20$ & $6090 \pm 40$ & $7020-6850$ & Bones (burial 5) & Beta 184619 \\
\hline Moraes & 130 & $5895 \pm 45$ & $6777-6665$ & Bones (burial 13) & KIA 15561 \\
\hline Timbuva & $20-30$ & $5740 \pm 50$ & $6660-6410$ & Shell & Beta 189339 \\
\hline Moraes & 35 & $5420 \pm 30$ & $6289-6174$ & Bones (burial 37) & KIA 20843 \\
\hline Alecrim I & $10-20$ & $5310 \pm 50$ & $6250-5940$ & Shell & Beta 189330 \\
\hline Capelinha & $30-40$ & $5000 \pm 70$ & $5910-5600$ & Shell & Beta 189332 \\
\hline Moraes & 100 & $4985 \pm 35$ & $5745-5658$ & Bones (burial 5) & KIA 15562 \\
\hline Capelinha III & $90-100$ & $4530 \pm 50$ & $5320-4990$ & Shell & Beta 189333 \\
\hline Moraes & 25 & $4511 \pm 32$ & $5200-5048$ & Bones (burial 25) & KIA 20844 \\
\hline Capelinha III & $90-100$ & $4500 \pm 40$ & $5310-4980$ & Charcoal & Beta 189334 \\
\hline Estreito & 130 & $4124 \pm 27$ & $4658-4567$ & Bones (burial 26) & KIA 20846 \\
\hline Tatupeva & $10-20$ & $3990 \pm 70$ & $4800-4770$ & Shell & Beta 184623 \\
\hline Estreito & 25 & $3655 \pm 26$ & $4011-3893$ & Bones (burial 1) & KIA 20845 \\
\hline Pavão II & $10-20$ & $3530 \pm 70$ & $3980-3640$ & Shell & Beta 178127 \\
\hline Itaoca I & $50-60$ & $1730 \pm 40$ & $1720-1540$ & Charcoal & Beta 189336 \\
\hline Gurutuba IV & $50-60$ & $1650 \pm 40$ & $1620-1430$ & Charcoal & Beta 189335 \\
\hline Caraça & $70-80$ & $1607 \pm 24$ & $1434-1416$ & Charcoal & KIA 20839 \\
\hline Pavão XVI & 30 & $1571 \pm 24$ & $1525-1408$ & Bones (burial 1) & KIA 20842 \\
\hline Itaoca I & $20-30$ & $1460 \pm 60$ & $1500-1280$ & Shell & Beta 178126 \\
\hline Lageado IV & $10-20$ & $1460 \pm 60$ & $1182-1062$ & Shell & Beta 178128 \\
\hline Caraça & $10-20$ & $1300 \pm 60$ & $1310-1070$ & Shell & Beta 178125 \\
\hline Guaract & $10-20$ & $1270 \pm 70$ & $1300-1050$ & Charco & Beta- 184621 \\
\hline Pavão III & 20 & $1219 \pm 24$ & $1182-1062$ & Bones (burial 1) & KIA 20840 \\
\hline
\end{tabular}

In Figure 2 and Table 1 above, it is possible to identify 3 chronological clusters, or periods. All the early dates (10,500-9000 cal yr BP) come from a few sites located in the southern Jacupiranguinha River area. About a millennium later, the second period (8000-3600 cal yr BP) displays what appears to be an expansion of the riverine sambaqui culture, with 9 sites dispersed throughout the valley. Finally, around $2000 \mathrm{yr}$ later, the third and last period (1700-1000 cal yr BP) seems to concentrate in the Itaoca region, the western, deeper inland, portion of the valley, perhaps a refuge area.

It is interesting to note the role of human bones as ${ }^{14} \mathrm{C}$ sample material, since in the riverine sambaqui archaeological context it is very rare to find an articulated hearth structure, despite the abundant diluted charcoal in the sediment. As burials are the most well-defined archaeological feature in these sites (Plens 2007), it makes them the most reliable source for ${ }^{14} \mathrm{C}$ analysis. Snail shells are abundant and organized in shell layers or pockets, disposed around and on top of the burials, and should be a major asset for dating. In our experience, however, shell packs associated with specific burials are often older than the burials themselves, so probably shells were taken from older burials. Thus, the shells can be used to establish site age, but they are not a reliable source for dating specific structures, especially when the site has been sequentially occupied - and covered with mounds-over long periods of time, as quite a few of them have. 
Radiocarbon datation Calibrated age (yrs BP)

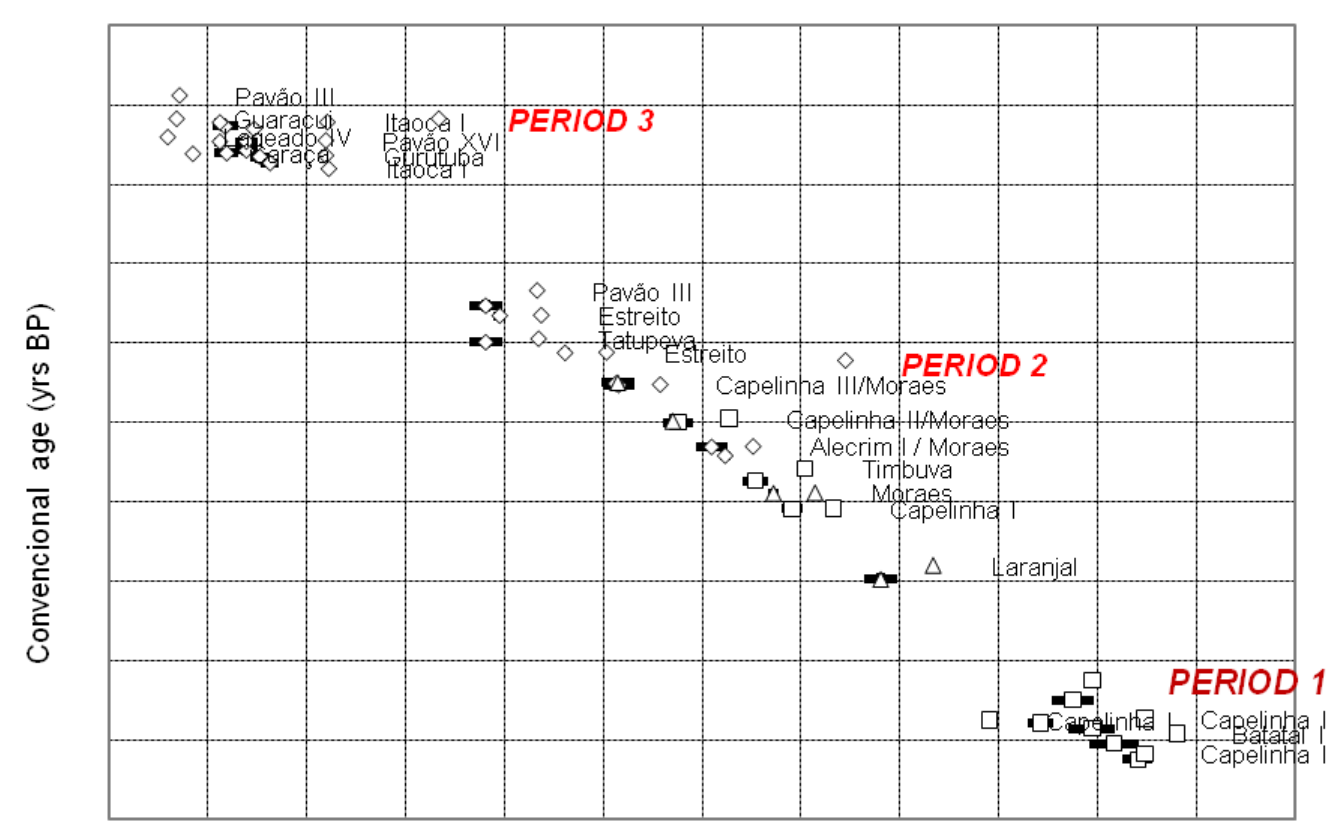

Figure 2 Plot of the dates for the riverine sambaquis from the Ribeira Valley

\section{DISCUSSION}

The data presented above point to an expansion that starts from the south to the north slightly before $10,000 \mathrm{cal}$ yr ago, suggesting a move inwards from the coast. Moreover, around $4500 \mathrm{yr}$ ago, the riverine sambaquis appear in the western portion of the Ribeira Valley, and this area seems to be their last redoubt in the region. Whether this represents successive migration episodes from the coast or a progressive populational expansion of the inland moundbuilders is not yet clear. Whatever possibility holds true, the coastal provenience of this inland colonization seems to be confirmed by the funerary moundbuilding tradition shared by both populations, as well as the chronological displacement from the coast towards the more inland portions of the valley.

Yet, the antiquity of these riverine moundbuilders, preceding the most ancient coastal mounds by more than $2000 \mathrm{yr}$, seems to make things a bit more complicated. These riverine mounds have endured for $9000 \mathrm{yr}$, a chronology even longer than the available chronology for the coastal sambaquis ( $7000 \mathrm{yr})$, which are, arguably, the source for the migrations of the inland moundbuilders. As a matter of fact, at the early inland sites (first period) some sea faunal remains have been retrieved, thus confirming an older human presence at the shore in this portion of the coast, as it happens elsewhere to the southern shores (e.g. Miller 1969). It has been suggested (e.g. DeBlasis et al. 2007) that the older coastal sambaquis were destroyed, or submerged, by sea-level oscillations occurring since the end of the Pleistocene- a rather plausible argument, but unfortunately still lacking hard evidence. On the other hand, the only human skeleton from the earlier period (burial 2 at Capelinha 1) has been described as having hinterland Paleoindian affiliation (Neves et al. 2005). Are the early riverine moundbuilders Paleoindians (which would make sense given the Umbu traits found therein) or are they sambaqui people? Would early sambaqui moundbuilders and Paleoindian occupations have a common ground? 


\section{Figuti et al.}

Bioanthropological evidence for periods 2 and 3 is not conclusive for the genetic affiliation of the riverine sambaqui moundbuilders, particularly regarding the coastal people. Based on the specificity of their cultural traits, Plens (2007) claims that the riverine moundbuilders have become culturally unique through time, distinct from other inland groups as well as the coastal sambaquis. But the gaps in the chronological sequence discussed above make the continuity of this riverine culture questionable. The strongest argument in favor of cultural continuity is the persistence of meaningful cultural patterns such as shellmound building associated with burial ground at repeatedly (re)visited permanent places, thus acting as persistent landscape locations and territorial marks. Other aspects of material culture, such as lithic and bone technologies, seem to show some variability, arguably due to local or temporal derivation more than to cultural disruption.

\section{CONCLUSION}

The research project at the Ribeira de Iguape valley has generated a series of ${ }^{14} \mathrm{C}$ dates for the riverine sambaquis, sampling sites from the Jacupiranguinha (5), Juquiá (3), and Itaoca (11) areas. The first, Jacupiranguinha, contains earlier riverine sambaquis (9250-8500 cal yr BP). After an interval of about $1500 \mathrm{yr}(8500-7000 \mathrm{cal}$ yr BP), a second phase (7000-3500 cal yr BP) is related to an expansion of the riverine sambaquis, represented by 9 sites spread all over the research area. A second interval of $1800 \mathrm{yr}$ take place between 3500 and $1700 \mathrm{cal} \mathrm{yr} \mathrm{BP}$, followed by a third and last period of riverine shellmound occupation (1700-1200 cal yr BP), with 7 sites recorded at the inland Itaoca region. The chronological sequence of ${ }^{14} \mathrm{C}$ ages presented here suggests that the riverine sambaquis inhabitants in the Ribeira de Iguape valley are among the earliest known for eastern South America, and the burial II from Capelinha site $(\sim 10,000 \mathrm{cal}$ yr BP) is the earliest known in São Paulo State.

Even if the evidence is still not conclusive, the structural features of these riverine inland shellmounds, recurrently associated with funerary burial and related festivities, led the authors to link them to the coastal sambaquis, where the same cultural traits are monumentally displayed, assuming paramount social meaning (Gaspar et al. 2008). In their displacement towards the hinterland, apparently in successive waves, or perhaps as a distinct population expansion through the Holocene as suggested by Plens (2007), these riverine people seem to have established frontier relations with inland Umbu hunter-gatherers, into the deep valleys encrusted along the piedmont of the southern Brazilian plateau escarpments. As these events have taken place since the late Pleistocene/early Holocene, and the evidence available remains very scanty, the bioanthropological and cultural nuancing of such a history is still waiting to be told.

\section{ACKNOWLEDGMENTS}

We are very thankful to the many students that have helped this long-term research project to come true. Grateful thanks also to Fundação de Amparo à Pesquisa do Estado de São Paulo (FAPESP) and the Alban Programme Scholarship.

\section{REFERENCES}

Alves CC. 2008. Análise zooarqueológica de um sambaqui fluvial: o caso do Sitio Capelinha I. Dissertação de Mestrado, PPGArq-USP.

Barreto CNGB. 1988. A ocupação pré-colonial do vale do Ribeira de Iguape, SP: os sítios concheiros do médio curso. Dissertação de Mestrado, FFLCH-USP.

Borges C. 2009. Analyse archéozoologique d'um amas- coquillier fluviatile: le site Laranjal. Dissertação de mestrado, Master Erasmus Mundus em Quaternaire et Préhistoire. Paris: Museum National d'Histoire Naturelle.

Collet GC. 1985. Novas informações sobre os sambaquis fluviais do Estado de São Paulo. Arquivos do Museu de História Natural da UFMG, Belo Horizonte. 


\section{Small Sambaquis and Big Chronologies}

DeBlasis P, Fish S, Gaspar MD, Fish P. 1998. Some references for the discussion of complexity among the sambaqui moundbuilders from the southern shores of Brazil. Revista de Arqueologia Americana 15:75-105. Mexico City: Instituto Panamericano de Geografia e Historia.

DeBlasis P, Kenip A, Scheel-Ybert R, Giannini P, Gaspar M. 2007. Sambaquis epaisagem Dinâmica natural e arqueologia regional do sul do Brasil. ArqueologiaSuramericana/Arqueologia Sul-Americana 3(1):2961.

Fish PR, Fish SK, DeBlasis P, Gaspar MD. 2013. Monumental shell mounds as persistent places in southern coastal Brazil. In: Thompson VD, Waggoner Jr JC, editor. The Archaeology and Historical Ecology of Small Scale Economies. Gainesville: University Press of Florida. p 120-40.

Gaspar MD, DeBlasis P, Fish SK, Fish P. 2008. Sambaqui (shell mound) societies of coastal Brazil. In: Silverman H, Isbell WH, editors. Handbook of South American Archaeology. Berlin: Springer. p 319-35.

Miller ET. 1969. Resultados preliminares das escavações no sítio pré-cerâmico RS-LN-01: Cerrito Dalpiaz (abrigo-sob-rocha). Iheríngia (Antropologia) 1:43116.
Morais JL. 1999-2000. Arqueologia da Região Sudeste. In: Neves W, editor. Dossiê antes de Cabral: arqueologia brasileira II. Revista USP 44:194-217.

Neves WA, Hubbe M, Okumura MMM, González-José R, Figuti L, Eggers S, DeBlasis P. 2005. A new early Holocene human skeleton from Brazil: implications for the settlement of the New World. Journal of Human Evolution 48(4):403-14.

Penin A. 2005. Análise dos processos formativos do sítio Capelinha: estabelecimento de um contexto micro-regional [Master's dissertation]. University of São Paulo.

Plens CR. 2007. Sítio Moraes, uma biografia não autorizada: análise da formação de um sambaqui fluvial. Tese de Doutorado, PPGArq-USP.Pp. 240 p.

Prous A. 1992. Arqueologia Brasileira. Brasília: Editora UnB.

Schmidt-Dias A. 2012. Hunter-gatherer occupation of south Brazilian Atlantic Forest: paleoenvironment and archaeology. Quaternary International 256:12-8.

Schmitz PI. 1987. Prehistoric hunters and gatherers of Brazil. Journal of World Prehistory 1(1):53-126.

Willey G. 1971. An Introduction to American Archaeology. Englewood Cliffs: Prentice-Hall. 